\title{
Optimasi Racing Line pada ECU (Electronic Control Unit) Mobil Listrik Berbasis Fuzzy Logic Control
}

\author{
WIDYA CAHYADI, MUH.FAZAUDDIYAK SA'ID, ALI RIZAL CHAIDIR
}

Teknik Elektro, Fakultas Teknik, Universitas Jember

Email: cahyadi@unej.ac.id

Received 3 Februari 2020| Revised 28 Maret 2020| Accepted 10 Mei 2020

\begin{abstract}
ABSTRAK
Racing line merupakan daerah lintasan yang berguna untuk pebalap atau pengemudi mendapatkan akselerasi maksimum. Dalam penelitian mobil listrik, racing line tidak hanya berguna untuk mendapatkan akselerasi maksimum, namun juga berguna untuk mendapatkan hasil efisiensi tertinggi terutama pada saat mobil berada di tikungan, hal ini disebabkan mobil listrik menghasilkan daya yang lebih besar pada saat berada di tikungan dibandingkan dengan lintasan lurus. Pemilihan racing line serta proses kontrol kecepatan pada mobil listrik yang baik pada tikungan bertujuan untuk mengurangi konsumsi daya pada motor serta meningkatkan hasil efisiensi mobil. Untuk dapat meningkatkan hasil efisiensi pada mobil listrik perlu ditambahkan sebuah ECU (Electronic Control Unit) dengan kontrol fuzzy logic sebagai pengendali kecepatan mobil secara otomatis pada saat mobil berada di tikungan, dengan penambahan kontrol fuzzy logic serta sensor sudut belok ini konsumsi daya yang dihasilkan oleh mobil saat berada di tikungan menjadi lebih rendah serta hasil efisiensi mobil lebih tinggi.
\end{abstract}

Kata kunci: Racing Line, Sistem ECU, Logika Fuzzy

\begin{abstract}
In the research of electric cars, the racing line is not only useful for getting maximum acceleration, but it is also useful to get the highest efficiency results especially when the car is round the corner, this is due to electric cars producing greater power when in a curved compared to a straight track. The selection of a racing line and speed control process on a good electric car on the curved aims to reduce the power consumption of the motor and increase the efficiency of the car. To be able to increase the efficiency of the electric car, an ECU (Electronic Control Unit) is added by fuzzy logic controls as a car speed controller automatically when the car is in the corner, with the addition of fuzzy logic controls and turn-angle sensors. The car when on the curved becomes lower and the results of higher car efficiency.
\end{abstract}

Keywords: Racing Line, ECU System, Fuzzy Logic 


\section{PENDAHULUAN}

Perkembangan teknologi mobil listrik pada saat ini berkembang sangat pesat, hal ini dapat dilihat dari berbagai penelitian dan produksi mobil listrik dari perusahaan mobil di dunia. Mobil listrik adalah mobil yang menggunakan listrik sebagai sumber tenaganya, karena keterbatasan akan bahan bakar fosil mobil listrik ini dianggap sebagai salah satu alternatif untuk menjawab permasalahan keterbatasan sumber energi. Dalam upaya pengembangan mobil listrik ini Indonesia, sudah banyak yang melakukan riset baik dilakukan oleh pemerintah melalui perguruan tinggi maupun pihak swasta. Selain itu di Indonesia sendiri juga sering diadakan kompetisi mobil listrik yang diikuti berbagai perguruan tinggi negeri maupun swasta dalam rangka mengembangkan teknologi mobil listrik dan meningkatkan kreativitas mahasiswa.

Dalam penelitian dan pembuatan sistem kontrol pada mobil listrik, sistem kontrol pada mobil dikenal dengan sistem ECU (Electronic Control Unit), dimana ECU ini akan berperan dalam proses kontrol dan manajemen sistem elektronik pada mobil (Alam, 2019). Selain itu ECU berfungsi sebagai pengendali dan pengukuran arus maupun tegangan pada mobil. Manajemen sistem elektronik ini sangat berpengaruh pada hasil efisiensi mobil, semakin besar arus yang dihasilkan, maka tingkat efisiensi yang dihasilkan semakin kecil. Secara teori pengertian efisiensi adalah ukuran tingkat penggunaan sumber daya dalam suatu proses. Sedangkan pada mobil listrik efisiensi adalah jarak terjauh yang dapat ditempuh oleh mobil dalam satuan $\mathrm{km} / \mathrm{kWh}$. Biasanya mobil menghasilkan arus yang besar ketika berada di tikungan, hal ini terjadi karena kerja dari motor listrik semakin berat, perubahan titik berat mobil, serta belum adanya sistem pengendali kecepatan otomatis untuk meminimalkan arus yang dihasilkan. Hal ini mengakibatkan berkurangnya hasil efisiensi pada mobil. Pada penelitian yang ber judul "Rancang Bangun Sistem Monitoring ECU (Electronic Control Unit) untuk Peningkatan Efisiensi Kerja Motor DC pada Mobil Listrik Universitas Jember" (Hardiyanto, 2016) proses pengendalian arus pada mobil listrik masih menggunakan ECU (Kusumo, 2015) dengan sistem semi otomatis menggunakan bantuan relay ON OFFuntuk mematikan dan menyalakan motor ketika arus yang terukur melebihi nilai yang telah ditentukan, penggunaan relay mekanis ini mengakibatkan lonjakan arus pada saat sistem bekerja.

Proses pengendalian kecepatan juga dilakukan oleh seorang operator atau wireless (Tripathy, 2017), menggunakan IoT untuk memonitoring (Babu, 2016), hal ini mengakibatkan proses pengendalian mobil listrik menjadi lebih lama dan dianggap kurang efisien. Maka diperlukan sebuah sistem yang dibuat untuk mengendalikan kecepatan, pengukuran arus dan tegangan otomatis sehingga dapat mengurangi konsumsi arus pada mobil, terutama pada saat mobil berada di tikungan, untuk mendapatkan hasil konsumsi daya yang paling kecil. Dengan adanya sistem pengendalian dan monitoring arus dan tegangan mobil pada tikungan secara otomatis dan real time (Chapman, 2005), diharapkan dapat meningkatkan tingkat efisiensi mobil. Penelitian ini menggunakan google spreadsheet sebagai media monitoring arus, tegangan, pwm dan sudut belok yang dikirimkan melalui jaringan internet. Selain sebagai sarana monitoring, sistem ini juga berfungsi sebagai pengendali kecepatan otomatis berbasis fuzzy logic contro/ pada saat mobil berada di tikungan. 


\section{METODE PENELITIAN}

Pada penelitian ini metode yang digunakan adalah membandingkan data hasil pengujian pada ECU (Electronic Control Unit) pada prototype mobil listrik tipe urban concept. Mobil listrik tipe urban concept ini merupakan prototype mobil dengan desain semirip mungkin dengan mobil pada umumnya, menggunakan 4 roda, 1 penggerak motor DC tipe inwheel, menggunakan sumber baterai litium ion $48 \mathrm{~V}$, bodi mobil, serta asesoris lampu beserta fungsinya. Data yang diambil pada penelitian ini adalah hasil pengujian efisiensi pada prototype mobil listrik antara metode pengendali motor berbasis fuzzy logic control dengan tanpa menggunakan metode fuzzy.

\subsection{Desain monitoring sistem ECU}

Untuk mempermudah dalam perancangan sistem, maka diperlukan beberapa komponen alat dan bahan penunjang. Alat dan bahan penunjang tersebut meliputi baterai, sensor ACS758, sensor pembagi tegangan, sensor control motor DC, motor DC, Arduino Nano, board NodeMCU, wifi router, dan Personal Computer (PC) yang sudah terdapat tampilan pada google docs. Dari beberapa alat dan bahan tersebut memiliki fungsi masing-masing dalam rangkaian sistem. Gambar 1 merupakan blok skema sistem ECU, dan Gambar 2 merupakan proses monitoring energi meter pada google docs (Yanuarti, 2016). Sistem monitoring yang digunakan adalah memanfaatkan sistem IoT, dengan menggunakan IoT hasil pembacaan sensor dapat dimonitoring dengan memanfaatkan jaringan internet (Junaidi, 2015)

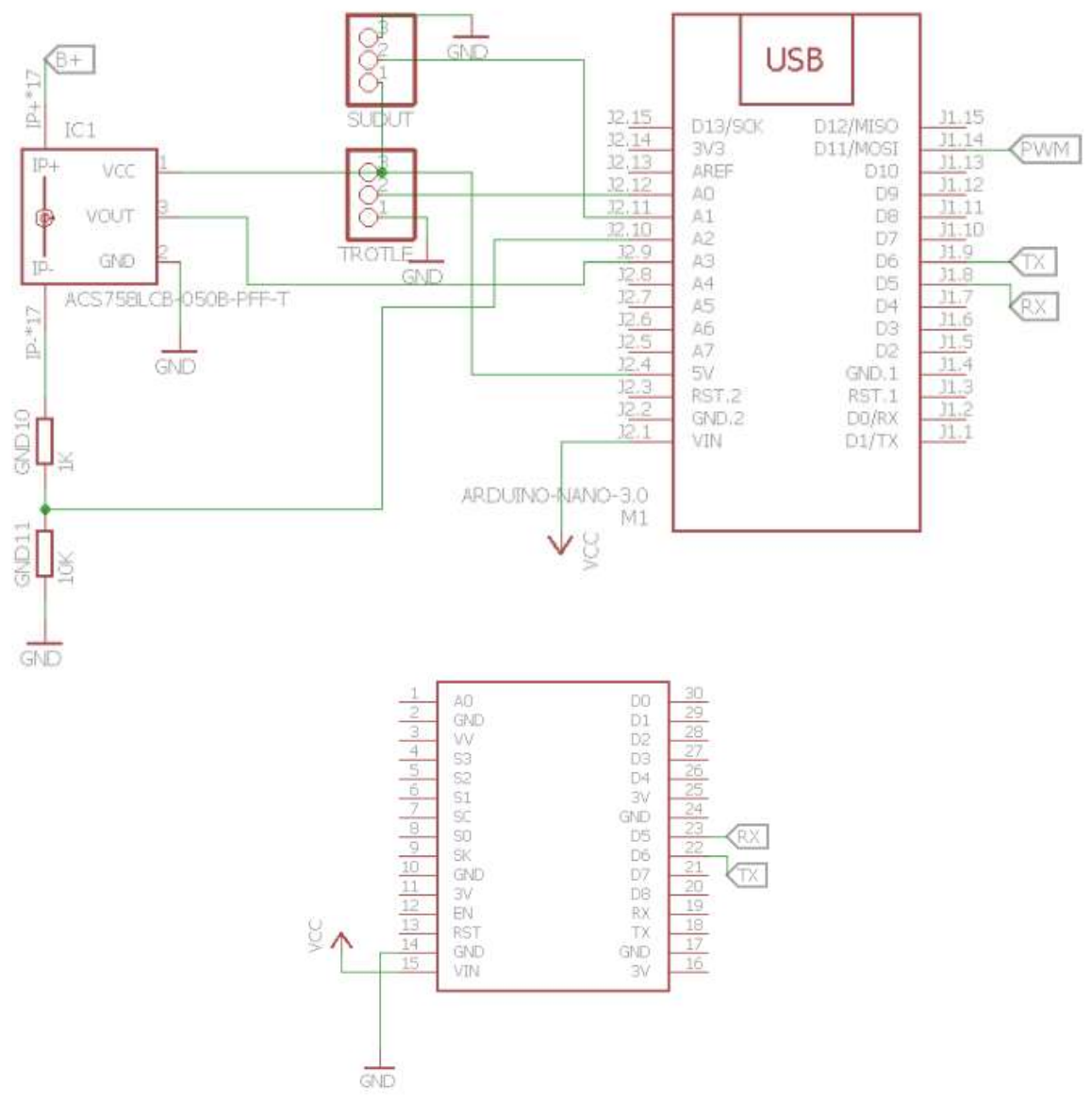

Gambar 1. Skematik ECU dan Modul Telemetri 


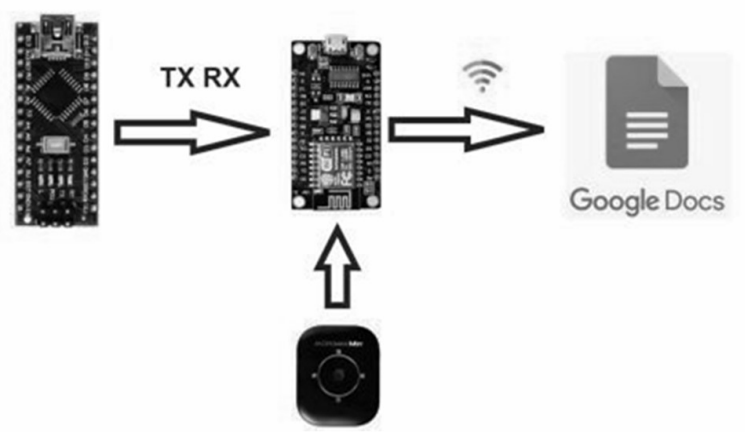

Gambar 2. Blok Diagram Proses Pengiriman Data

\subsection{Kontrol Fuzzy}

Kontrol yang digunakan pada penelitian ini adalah Logika Fuzzy, Logika Fuzzy digunakan untuk mendukung sebuah keputusa (Hadiyosi, dkk, 2015) (Valášková, dkk, 2014). Himpunan Fuzzy digunakan untuk memperluas jangkauan fungsi karakteristik sehingga fungsi tersebut dapat mencakup bilangan rea/ pada interval antara 0 dan 1 . Sehingga nilai yang didapatkan tidak hanya ada dua macam yaitu benar (1) dan salah (0), akan tetapi masih ada nilai yang terletak diantara benar dan salah. Dalam penelitian kali ini, Fuzzy digunakan memanajemen kinerja ECU. Membership Fuzzy yang digunakan ada empat yaitu arus, pwm input, pwm output dan sudut belok. (Kusumadewi, 2010).

Tabel 1. Himpunan Fuzzy Parameter Arus

\begin{tabular}{|c|c|}
\hline Parameter & Nilai (A) \\
\hline Arus Kecil & $0-6$ \\
\hline Arus Sedang & $2-13$ \\
\hline Arus Besar & $9-15$ \\
\hline
\end{tabular}

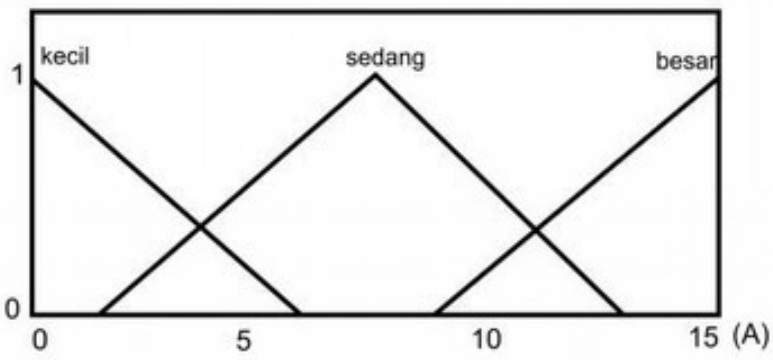

Gambar 3. Representasi Variabel Himpunan Fuzzy Arus

Himpunan fuzzy pada parameter PWM input memiliki 3 himpunan, yaitu himpunan pwm rendah dengan nilai 0-100, himpunan pwm sedang dengan rentang nilai 25-225, dan himpunan pwm tinggi dengan rentang nilai 150-255. Nilai PWM input ini diperoleh dari hasil pembacaan potensiometer pada throttle mobil. Representasi himpunan PWM input ditunjukkan pada Gambar 4. 
Tabel 2. Himpunan Parameter PWM input

\begin{tabular}{|c|c|}
\hline Parameter & Nilai (8 bit) \\
\hline Rendah & $0-100$ \\
\hline Sedang & $25-225$ \\
\hline Tinggi & $150-255$ \\
\hline
\end{tabular}

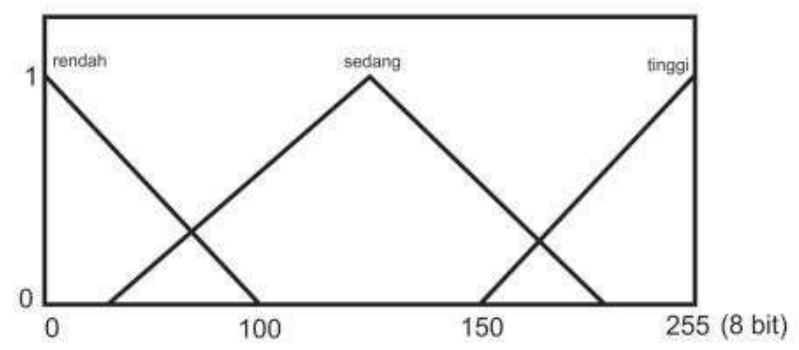

Gambar 4. Representasi Himpunan Fuzzy PWM input

Himpunan fuzzy pada parameter sudut memilik 3 himpunan yaitu himpunan kirifull dengan nilai -20 sampai -60 derajat, himpunan sedang dengan nilai -21 sampai 21 derajat, dan himpunan kananfull dengan nilai antara 20 sampai dengan 60 derajat. Parameter sudut ini diperoleh dari hasil pembacaan sensor sudut yang dipasang pada as kemudi mobil. Representasi himpunan parameter sudut ditunjukkan pada Gambar 5.

Tabel 3. Himpunan Parameter Sudut

\begin{tabular}{|c|c|}
\hline Parameter & Nilai $\left({ }^{\circ}\right)$ \\
\hline Kirifull & $-20--60$ \\
\hline Sedang & $-21-21$ \\
\hline Kananfull & $20-60$ \\
\hline
\end{tabular}

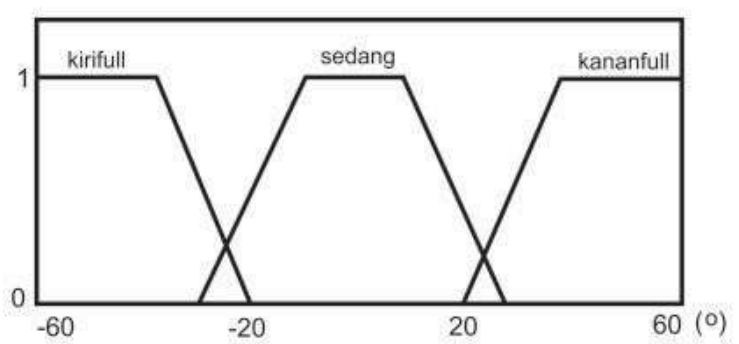

Gambar 5. Representasi Himpunan Fuzzy Sudut

Himpunan parameter PWM output memiliki 3 himpunan anggota, seperti pada PWM input, yaitu himpunan rendah, sedang, dan tinggi. Representasi himpunan PWM output ditunjukkan pada Gambar 6. 
Tabel 4. Himpunan Parameter PWM ouput

\begin{tabular}{|c|c|}
\hline Parameter & Nilai (8 bit) \\
\hline Rendah & $0-100$ \\
\hline Sedang & $25-225$ \\
\hline Tinggi & $150-255$ \\
\hline
\end{tabular}

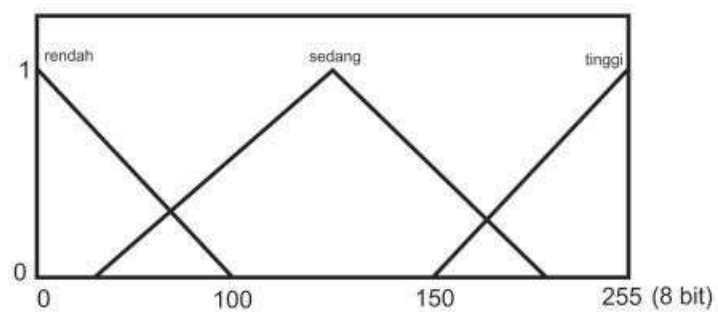

Gambar 6. Representasi Himpunan PWM Ouput

\subsection{Rangkaian Driver Motor DC}

Driver motor pada alat digunakan untuk mengendalikan motor pada mobil listrik. Rangkaian driver motor ini terdiri dari beberapa komponen utama yaitu baterai, dioda, resistor, kapasitor, optocopler 817, dan mosfet.

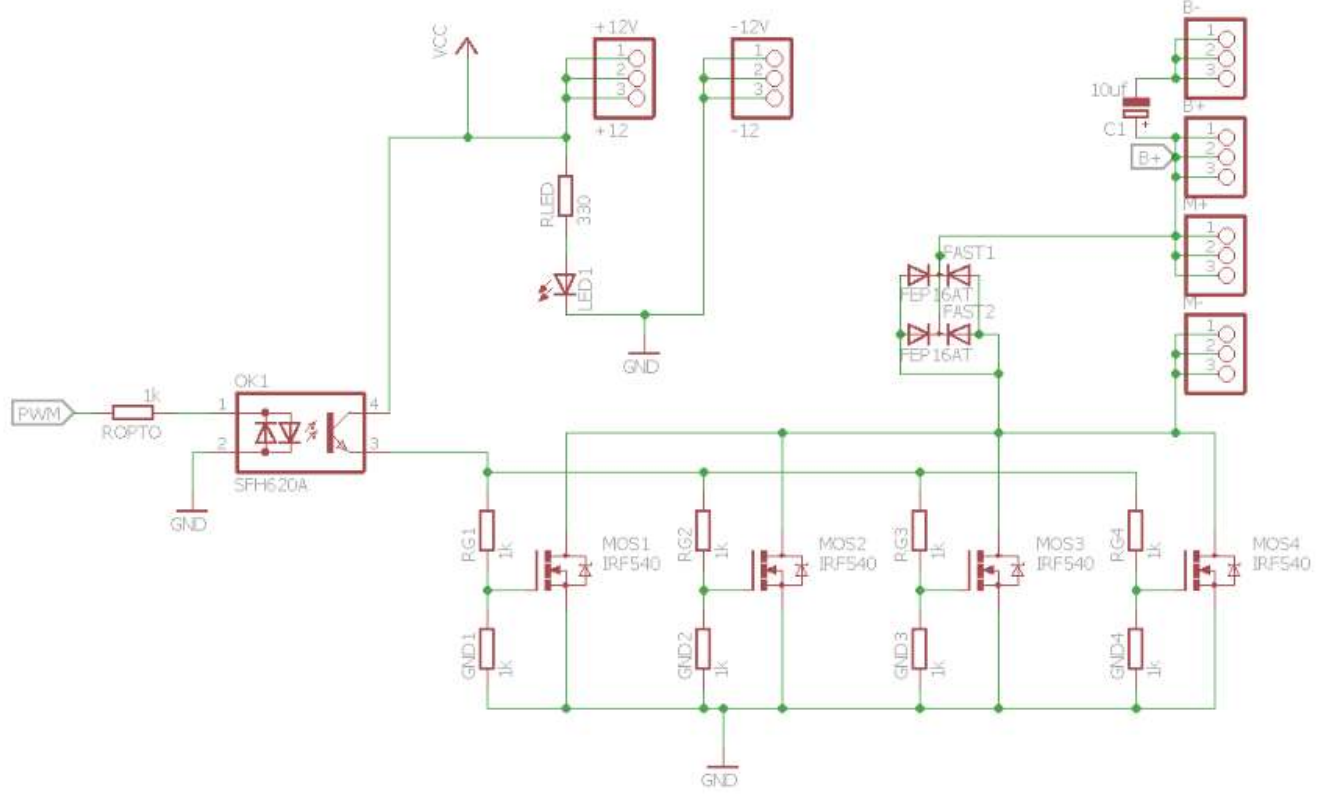

Gambar 7. Rangkaian Driver Motor DC

Dimana rangkaian memperoleh sumber tegangan dari baterai $36 \mathrm{~V}$ yang diturunkan menjadi $12 \mathrm{~V}$. Untuk dapat memutar motor, mosfet pada rangkaian harus diaktifkan. Tegangan yang dibutuhkan untuk mengaktifkan yaitu sebesar $12 \mathrm{~V}$ yang didapatkan dari proses switching optocupler 817. Nilai pwm output yang diperoleh dari proses kontrol fuzzy akan mengaktifkan rangkaian optocoupler dan mengaktifkan gate dari mosfer IRF540. Gambar rangkaian driver motor dapat dilihat seperti Gambar 7 (Setiawan, 2012) 


\subsection{Diagram Blok Kontrol Fuzzy}

Kontrol yang digunakan pada penelitian ini adalah untuk menjalankan sistem adalah kontrol FIS yang melakukan perubahan parameter secara otomatis berdasarkan perubahan pada kondisi lingkungan. Nilai PWM output akan berubah sesuai dengan hasil pembacaan parameter arus yang dihasilkan oleh motor DC, serta hasil pembacaan sudut belok yang dihasilkan oleh mobil ketika berada pada tikungan. PWM output akan mengatur besar tegangan yang masuk ke motor DC pada penggerak mobil.

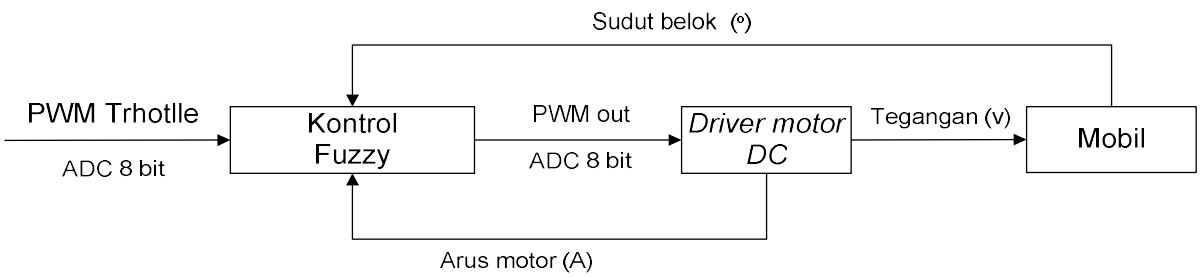

Gambar 8. Blok Diagram Kontrol Fuzzy

\section{HASIL DAN PEMBAHASAN}

\subsection{Pengujian Sensor Arus}

Pada sensor arus dilakukan kalibrasi dan pengujian untuk mendapatkan hasil pengukuran, berupa nilai arus yang terbaca pada sensor sesuai seperti hasil pengukuran menggunakan amperemeter digital. Untuk sensor arus digunakan jenis ACS758. Keluaran dari sensor arus adalah nilai data analog yang nantinya masuk mikrokontroler dikonversi menjadi data digital. Perubahan nilai hasil data digital nantinya akan dibandingkan terhadap hasil pengukuran pada amperemeter dengan variasi arus yang berbeda. Data hasil kalibrasi sensor arus ditampilkan pada Tabel 5.

Tabel 5. Pengujian sensor arus

\begin{tabular}{|c|c|c|c|c|}
\hline$\%$ & $\begin{array}{c}\text { Arus } \\
\text { Sensor (A) }\end{array}$ & Arus Terbaca (A) & dI (A) & No \\
\hline 0.00 & 0 & 0 & 0 & 1 \\
\hline 0.00 & 0.1 & 0.1 & 0.09 & 2 \\
\hline 5.26 & 0.19 & 0.2 & 0.19 & 3 \\
\hline 3.45 & 0.29 & 0.3 & 0.29 & 4 \\
\hline 2.56 & 0.39 & 0.4 & 0.39 & 5 \\
\hline 2.04 & 0.49 & 0.5 & 0.48 & 6 \\
\hline 1.69 & 0.59 & 0.6 & 0.58 & 7 \\
\hline 1.45 & 0.69 & 0.7 & 0.68 & 8 \\
\hline 1.27 & 0.79 & 0.8 & 0.79 & 9 \\
\hline 1.12 & 0.89 & 0.9 & 0.88 & 10 \\
\hline 0.00 & 1 & 1 & 0.99 & 11 \\
\hline 0.00 & 1.1 & 1.1 & 1.08 & 12 \\
\hline 0.84 & 1.19 & 1.2 & 1.18 & 13 \\
\hline 0.76 & 1.31 & 1.3 & 1.29 & 14 \\
\hline 0.00 & 1.4 & 1.4 & 1.39 & 15 \\
\hline 0.67 & 1.49 & 1.5 & 1.48 & 16 \\
\hline 1.27 & 1.58 & 1.6 & 1.58 & 17 \\
\hline 0.00 & 1.7 & 1.7 & 1.69 & 18 \\
\hline 0.55 & 1.81 & 1.8 & 1.78 & 19 \\
\hline 0.52 & 1.91 & 1.9 & 1.88 & 20 \\
\hline 1.17 & & Rata-rata eror & & \\
\hline
\end{tabular}


Berdasarkan data yang telah didapatkan dari hasil kalibrasi dan pengujian sensor arus dalam satuan Ampere terdapat rata-rata eror sebesar 1,17\%. Eror terbesar terdapat saat pembacaan sensor tegangan sebesar 0,19 A dengan hasil pembacaan amperemeter $0,2 \mathrm{~A}$. Sedangkan eror terkecil terdapat saat pembacaan sensor tegangan sebesar $1 \mathrm{~A}$ dengan hasil pembacaan amperemeter $1 \mathrm{~A}$ yaitu sebesar $0 \%$. Pada grafik diperoleh suatu persamaan $Y=1,0048 x+0,01$ ini akan dimasukan kedalam mikrokontroler.

Kalibrasi Sensor Arus

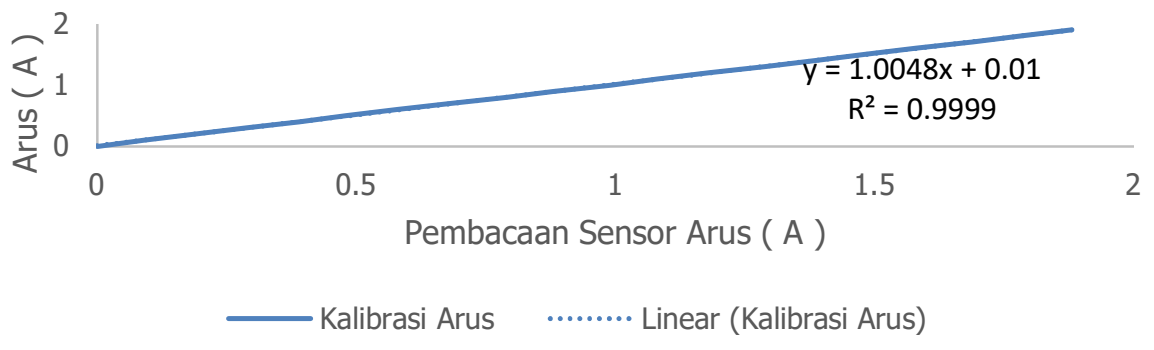

Gambar 9. Kalibrasi Sensor Arus

\subsection{Pengujian Sensor Tegangan}

Pada sensor ini dilakukan kalibrasi dan pengujian untuk mendapatkan hasil pengukuran nilai tegangan terbaca pada sensor, sesuai dengan hasil pengukuran menggunakan voltmeter digital. Untuk sensor tegangan digunakan dua resistor dengan konsep pembagi tegangan. Keluaran dari sensor tegangan adalah nilai data analog yang nantinya masuk mikrokontroler dikonversi menjadi data digital.

Tabel 6. Pengujian Sensor Tegangan

\begin{tabular}{|c|l|l|l|l|}
\hline No & $\begin{array}{c}\text { ADC } \\
(\mathbf{1 0} \text { bit) }\end{array}$ & $\begin{array}{c}\text { Tegangan } \\
\text { Terbaca (V) }\end{array}$ & $\begin{array}{c}\text { Tegangan } \\
\text { Sensor (V) }\end{array}$ & $\begin{array}{c}\text { E } \\
\mathbf{( \% )}\end{array}$ \\
\hline 1 & 705 & 37.25 & 37.23 & 0.054 \\
\hline 2 & 709 & 37.5 & 37.49 & 0.027 \\
\hline 3 & 713 & 37.75 & 37.75 & 0.000 \\
\hline 4 & 717 & 38 & 38.01 & 0.026 \\
\hline 5 & 721 & 38.25 & 38.27 & 0.052 \\
\hline 6 & 726 & 38.5 & 38.48 & 0.052 \\
\hline 7 & 731 & 38.75 & 38.48 & 0.702 \\
\hline 8 & 736 & 39 & 39 & 0.000 \\
\hline 9 & 741 & 39.25 & 39.26 & 0.025 \\
\hline 10 & 747 & 39.5 & 39.52 & 0.051 \\
\hline 11 & 751 & 39.75 & 39.72 & 0.076 \\
\hline 12 & 756 & 40 & 39.98 & 0.050 \\
\hline 13 & 761 & 40.25 & 40.24 & 0.025 \\
\hline 14 & 766 & 40.5 & 40.5 & 0.000 \\
\hline 15 & 770 & 40.75 & 40.76 & 0.025 \\
\hline 16 & 775 & 41 & 41.02 & 0.049 \\
\hline 17 & 780 & 41.25 & 41.23 & 0.049 \\
\hline 18 & 780 & 41.5 & 41.49 & 0.024 \\
\hline 19 & 790 & 41.75 & 41.75 & 0.000 \\
\hline 20 & 795 & 42 & 42.01 & 0.024 \\
\hline Rata-rata eror & & 0.065 \\
\hline
\end{tabular}

ELKOMIKA - 461 
Perubahan nilai hasil data digital nantinya akan dibandingkan terhadap hasil pengukuran pada voltmeter dengan variasi tegangan yang berbeda. Data hasil perbandingan antara sensor tegangan dengan voltmeter ditampilkan pada Tabel 6 . Berdasarkan data yang telah didapatkan dari hasil kalibrasi dan pengujian sensor tegangan dalam satuan Volt terdapat rata-rata eror sebesar $0,065 \%$. Eror terbesar terdapat saat pembacaan sensor tegangan sebesar 38,48 V dengan hasil pembacaan voltmeter $38,75 \mathrm{~V}$. Sedangkan eror terkecil terdapat saat pembacaan sensor tegangan sebesar $37,75 \mathrm{~V}$ dengan hasil pembacaan voltmeter $37,75 \mathrm{~V}$ yaitu sebesar $0 \%$. Pada grafik yang telah diuji diperoleh suatu persamaan $Y=0,0525 x+0,3271$ ini akan dimasukan kedalam mikrokontroler.

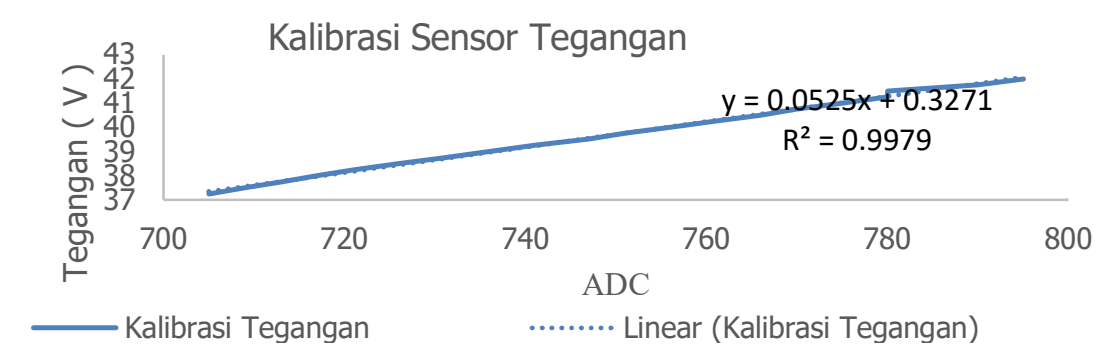

\section{Gambar 10. Kalibrasi Sensor Tegangan}

\subsection{Pengujian Sensor Sudut}

Pada sensor sudut belok ini dilakukan pengujian untuk mendapatkan hasil pengukuran pada sensor dengan perbandingan pengukuran menggunakan penggaris sudut. Sensor yang digunakan pada sudut belok ini adalah sebuah potensiometer yang dipasang sejajar dengan as stir mobil, keluaran dari sensor ini berupa nilai analog yang akan diterima oleh mikrokontroller dan diolah menggunakan metode mapping dengan rentan nilai -60 sampai dengan 60 derajat. Data hasil perbandingan antara sensor sudut belok dengan penggaris sudut ditampilkan pada Tabel 7.

Tabel 7. Pengujian Sensor Sudut Belok

\begin{tabular}{|c|l|l|l|l|}
\hline No & $\begin{array}{c}\text { ADC } \\
(\mathbf{1 0} \text { bit) }\end{array}$ & $\begin{array}{c}\text { Sudut } \\
\text { Busur } \\
\text { (derajat) }\end{array}$ & $\begin{array}{c}\text { Sensor Sudut } \\
\text { Belok } \\
\text { (derajat) }\end{array}$ & $\mathbf{E ( \% )}$ \\
\hline 1 & 372 & -60 & -60 & 0.00 \\
\hline 2 & 396 & -50 & -49 & 2.04 \\
\hline 3 & 418 & -40 & -39 & 2.56 \\
\hline 4 & 441 & -30 & -30 & 0.00 \\
\hline 5 & 464 & -20 & -20 & 0.00 \\
\hline 6 & 488 & -10 & -10 & 0.00 \\
\hline 7 & 510 & 0 & 0 & 0.00 \\
\hline 8 & 533 & 10 & 10 & 0.00 \\
\hline 9 & 557 & 20 & 20 & 0.00 \\
\hline 10 & 580 & 30 & 31 & 3.23 \\
\hline 11 & 603 & 40 & 39 & 2.56 \\
\hline 12 & 627 & 50 & 50 & 0.00 \\
\hline 13 & 651 & 60 & 60 & 0.00 \\
\hline
\end{tabular}


Dari hasil pengujian yang dilakukan, rata-rata eror persen pengukuran sebesar $0.79 \%$. Eror persen terbesar diperoleh pada pengujian sudut 30 derajat yaitu sebesar $3.23 \%$, sedangkan eror persen terkecil adalah $0 \%$ pada data ke 1, 4-9, dan data ke 12-13. Pada grafik diperoleh suatu persamaan $\mathrm{Y}=0,431 \mathrm{x}-220,4$ ini akan dimasukan kedalam mikrokontroler.

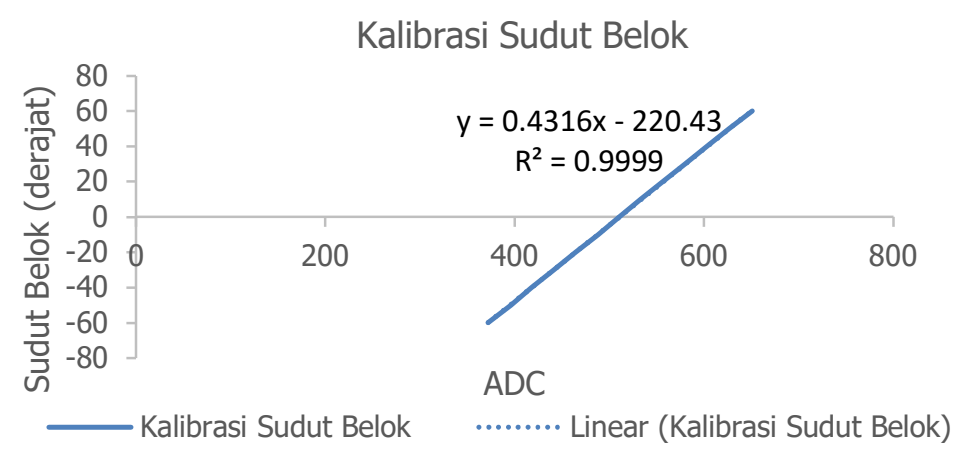

Gambar 11. Kalibrasi Sudut Belok

\subsection{Pengujian Sistem Tanpa Metode}

Pengujian ini bertujuan untuk mengetahui daya yang dihasilkan dari pengujian dinamis sistem ECU yang dibuat. Pengujian dilakukan dengan melakukan uji dinamis pada lintasan sepanjang $0,4 \mathrm{~km}$ atau 1 putaran penuh. Data hasil pengujian sistem tanpa metode ini dapat dilihat dari Grafik 12.

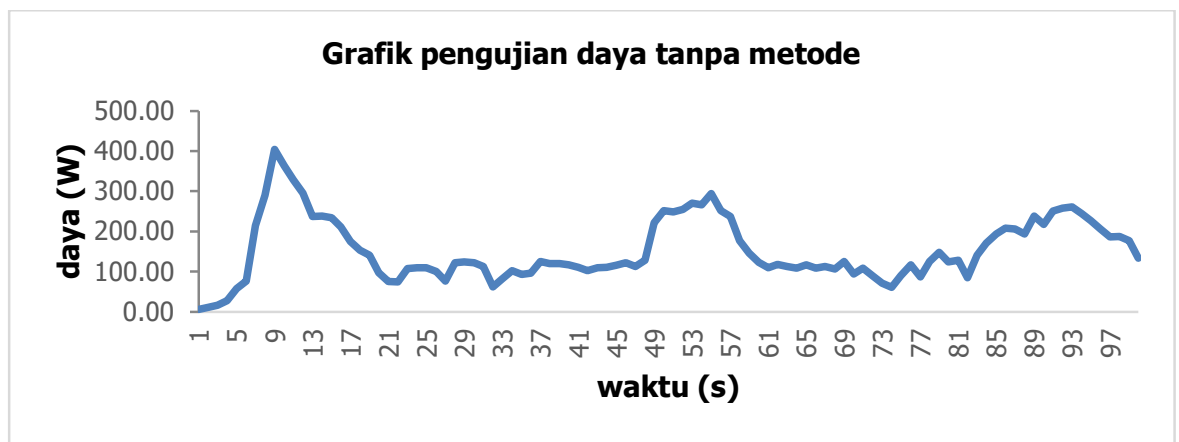

Gambar 12. Grafik Daya Pengujian Tanpa Metode

Dari Gambar 12 Grafik pengujian daya tanpa menggunakan metode ini, daya yang dihasilkan oleh mobil pada tiap waktu tidak stabil, hal ini dikarenakan besar arus yang dihasilkan oleh motor selalu berubah-ubah, pada saat data ke 1 sampai ke 9, terlihat terdapat lonjakan daya yang cukup tinggi, yaitu sebesar 404.12 Watt, hal ini disebabkan karena mobil yang awalnya dalam posisi diam mulai berjalan, hal ini menimbulkan lonjakan arus sehingga daya yang dihasilkan besar. Pada saat data ke 49 sampai 57 terjadi lonjakan daya sebesar 252.65 Watt dan pada data ke 89 sampai 96 terjadi lonjakan daya sebesar 238.95 Watt, hal ini disebabkan karena mobil berada pada belokan sehingga motor listrik mendapatkan beban yang berlebih, sehingga arus yang dihasilkan semakin besar.

\subsection{Pengujian Sistem Dengan Metode Fuzzy Logic Control}

Pada pengujian ini sistem ECU (Electronic control unit) diuji secara dinamis pada lintasan dengan jarak tempuh $0,4 \mathrm{~km}$. Pengujian ini bertujuan untuk menganalisa daya yang dihasilkan oleh mobil, terutama pada saat mobil berada pada tikungan. 


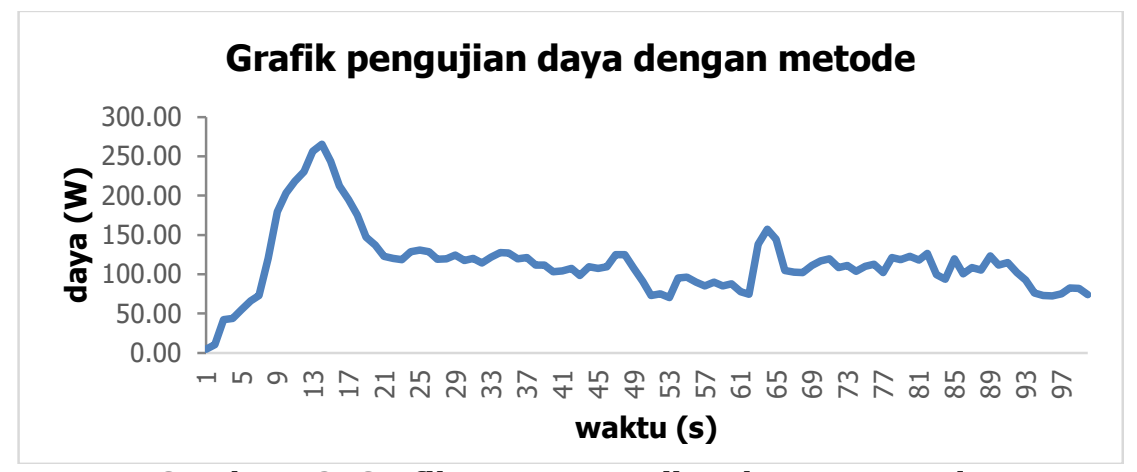

Gambar 13. Grafik Daya Pengujian dengan Metode

Dari Gambar 13 grafik pengujian daya sistem kontrol ECU menggunakan metode fuzzy logic control, terlihat daya yang dihasilkan pada grafik lebih stabil jika dibandingkan dengan pengujian sebelumnya, hal ini dikarenakan kecepatan mobil dapat menyesuaikan atau dikendalikan secara otomatis oleh ECU. Pada saat mobil mulai berjalan terjadi lonjakan daya sebesar 265.43 Watt, hal ini disebabkan karena seluruh beban mobil dibebankan pada motor listrik, sehingga arus yang dihasilkan semakin besar, ketika mobil sudah berjalan dalam beberapa saat maka daya yang dihasilkan oleh motor mengalami penurunan. Pada saat mobil berada pada belokan, arus yang dihasilkan relative kecil, berkisar antara 2.06 sampai dengan 2.57 Ampere, hal ini dikarenakan kecepatan mobil akan menyesuaikan dengan hasil pembacaan sudut belok dan arus yang diproses oleh ECU menggunakan fuzzy logic control, meskipun joki menambah kecepatan mobil, jika arus yang dihasilkan besar maka mobil tetap pada kecepatan yang telah ditentukan pada program fuzzy-nya.

Pada pengujian ini jarak yang digunakan hanya sepanjang 0,4 km. Ini merupakan sample pengujian dengan 1 putaran penuh. Peneliti tidak membahas data pada pengujian sebanyak 8 putaran penuh atau sepanjang 3,2 km dikarenakan banyaknya data serta nilai efisiensi yang dihasilkan oleh mobil hanya selisih 0,029 km/kwh. Hasil pengujian pada jarak 3,2 km atau 8 putaran menghasilkan energi total sebesar 25,457 Watt hours, atau sebesar 125,702 km/kWh.

\subsection{Pengujian Software}

Untuk menampilakan data hasil pengukuran ECU (Electronic Control Unit) pada mobil, peneliti menggunakan salah satu fitur yang tersedia di google, yaitu google spreadsheet. Tampilan pada google spreadsheet ditunjukkan pada Gambar 14. Data pengukuran yang dibaca oleh mikrokontroller arduino akan dikirimkan secara serial ke board nodeMCU, kemudian board nodeMCU mengirimkan data ke google spreadsheet melalui jaringan internet, tampilan software monitoring pada google docs meliputi timestamp untuk mengetahui waktu dan tanggal terima data dari nodeMCU, kemudian arus, tegangan, pwm, dan sudut belok. Pengiriman data yang dilakukan per 1 detik sekali, jika dalam kondisi sinyal atau koneksi internet yang bagus, tidak terdapat delay yang lama sehingga proses monitoring bisa benarbenar real time. Data yang ditampilkan dalam google docs ini sudah dalam bentuk kolom dan tabel serta otomatis tersimpan pada google drive. Data juga dapat diunduh dengan format .xlsx, .ods, .pdf, .html, .csv maupun. tsv. 


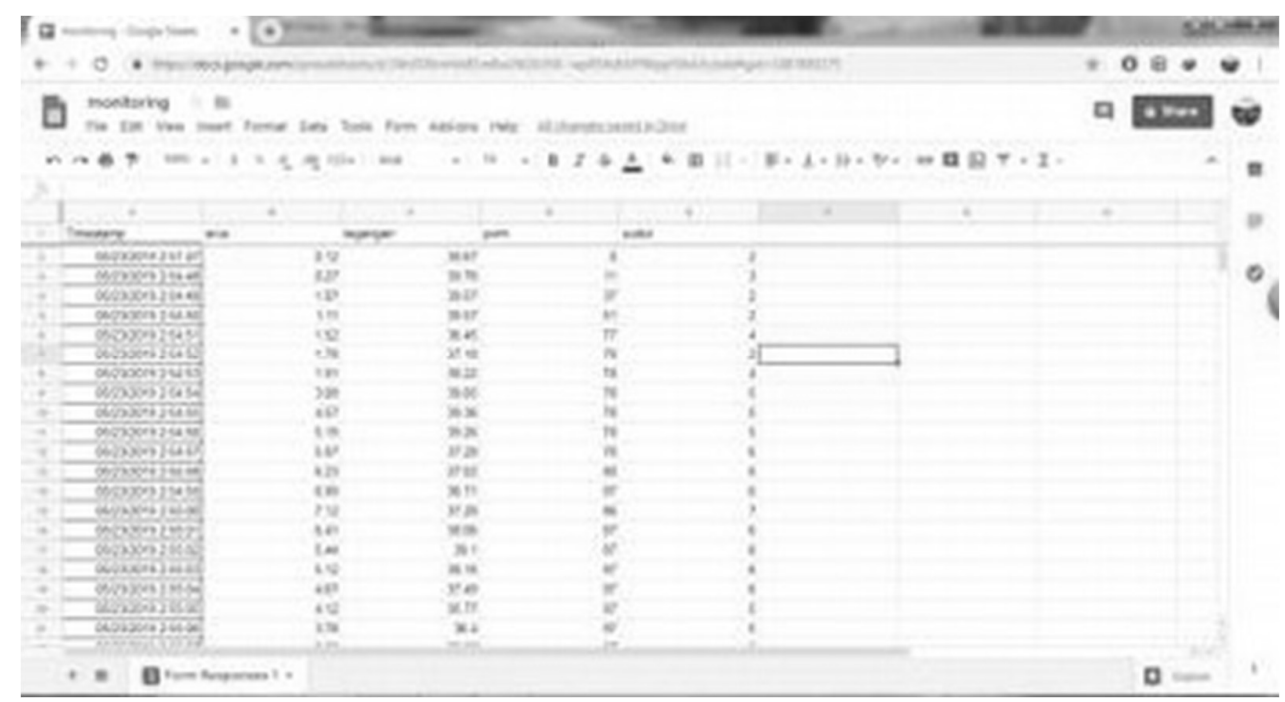

Gambar 14. Pengujian Software

\section{KESIMPULAN}

Dari hasil penelitian ini dapat ditarik beberapa kesimpulan, diantaranya adalah rancangan hardware ECU (Electronic Control Unit) pada mobil listrik berjalan dengan baik, sebagai kontrol kecepatan serta manajemen daya pada mobil. Proses monitoring energi meter dapat berfungsi sesuai dengan tujuan penelitian, pengiriman data energi menggunakan media jaringan internet dan google docs sebagai media penyimpan data. Nilai jarak tempuh yang dihasilkan oleh mobil listrik menggunakan metode fuzzy logic control lebih efisien yaitu sebesar 125,731 $\mathrm{Km} / \mathrm{kWh}$, daripada tanpa menggunakan metode sebesar 93,8344 Km/kWh. Penggunaan daya rata-rata pada saat pengujian dinamis menggunakan metode fuzzy logic control sebesar 114,53 Watt dan tanpa menggunakan metode fuzzy logic control sebesar 153,462 watt. Arus puncak yang dihasilkan oleh mobil pada saat berada di tikungan dengan menggunakan metode fuzzy logic control lebih kecil sebesar 3.11 Ampere daripada tanpa menggunakan metode sebesar 8,59 Ampere. Penelitian ini dapat dilanjutkan dengan menambahkan beberapa sensor pada ECU (Electronic Control Unit) seperti sensor tekanan ban, sensor kemiringan mobil, dan sensor getaran, sehingga dapat diketahui pengaruhnya terhadap efisiensi mobil.

\section{DAFTAR RUJUKAN}

Alam, Md S. Ul. (2019). Securing Vehicle Electronic Control Unit (ECU) Communications and Stored Data. Kingston: Queen's University.

Babu, R S. T. P. (2016). Internet of Things (IOT) Based Weather Monitoring system. International Journal of Engineering Research \& Technology (IJERT), 8 (4),105-109.

Chapman, S. J. (2005). Electric M Achinery Rjndamentals. Fourth Edition. New York: McGraw, Hill. 
Hadiyosi, S., Nursanto., Rizal, A. (2015). Implementasi Regulator Oksigen Otomatis berdasarkan Tingkat Pernafasan Menggunakan Logika Fuzzy. Jurnal Elkomika, 1 (3), 52-63.

Hardiyanto, D. L. (2016). Rancang Bangun Monitoring Sistem ECU (Electronic Control Unit) untuk Peningkatan Efisiensi Kerja Motor Dc pada Mobil Listrik Universitas Jember. Jember: Universitas Jember.

Junaidi, A. (2015). Internet of Things, Sejarah, Teknologi dan Penerapannya : Review. Jurnal IImiah Teknologi Informasi Terapan, 1 (3), 62-66.

Kusumo, Y. P. (2015). Rancang Bangun Sistem General Diagnostic Scanner Untuk Mengakses ECU Mobil Dengan Komunikasi Serial Obd-2. JCONES - Journal of Control and Network Systems, 69-82.

Kusumadewi, S. (2010). Aplikasi Logika Fuzzy. Yogyakarta: Graha Ilmu.

Setiawan, M. R., Muslim, M. A., dan Nusantoro, G. D. (2012). Kontrol Kecepatan Motor DC Dengan Metode PID Menggunakan Visual Basic 6.0 Dan Mikrokontroler ATmega 16. EECCIS, 1-6.

Tripathy, B. K. J. A. (2017). Internet of Things (IoT): Technologies, Applications, Challenges and Solutions. India: CRC Press.

Valášková, K., Kliestik, T., Mišanková, M. (2014). The Role of Fuzzy Logic in Decision Making Process. 2nd International Conference on Management Innovation and Business Innovation (ICMIBI), Volume 44.

Yanuarti, C. (2016). Sistem Monitoring Pengukuran Arus dan Tegangan Pada Alat Uji Efisiensi Motor DC Mobil Listrik Universitas Jember Berbasis Arduino Uno. Jember: Universitas Jember. 